\title{
obituary
}

\section{Colin Stansfield Smith:}

\section{Richard Weston}

Colin Stansfield Smith, who died in June 2013 following a stroke, was appointed Hampshire County Architect in 1973. During the following two decades, the studio he led produced the last major body of public sector buildings in Britain, an achievement that led to the award of the Royal Gold Medal for Architecture in 1991 and a

knighthood two years later.

Born in 1932, Stansfield Smith entered the Cambridge School of Architecture in 1953 after two years of National Service. He won the Edward S. Prior Prize in 1956, as well as a 'blue' for cricket. Gifted with bat and ball he played cricket for Lancashire and selection for the England team almost certainly beckoned. But he opted instead for a career in architecture, entering the London County Council's schools division in 1958. He left two years later for private practice with Emberton Tardrew and Partners - an office founded by the leading British Modernist Joseph Emberton - of which he became a full partner. In 1961 he married Angela Earnshaw, whose lifelong support was the bedrock of his professional achievements, and ten years later he joined Cheshire County Council as Deputy County Architect. In 1973 he was invited to head the office of Hampshire County Council.

The early '7os were in many ways an opportune time for an ambitious new County Architect. Hampshire was the biggest and most influential player in SCOLA - the Second Consortium of Local Authorities - whose prefabricated school-building system was beginning to reveal its shortcomings. Not only were the flat-roofed schools leaky, they were also environmental disasters,

1932-2013

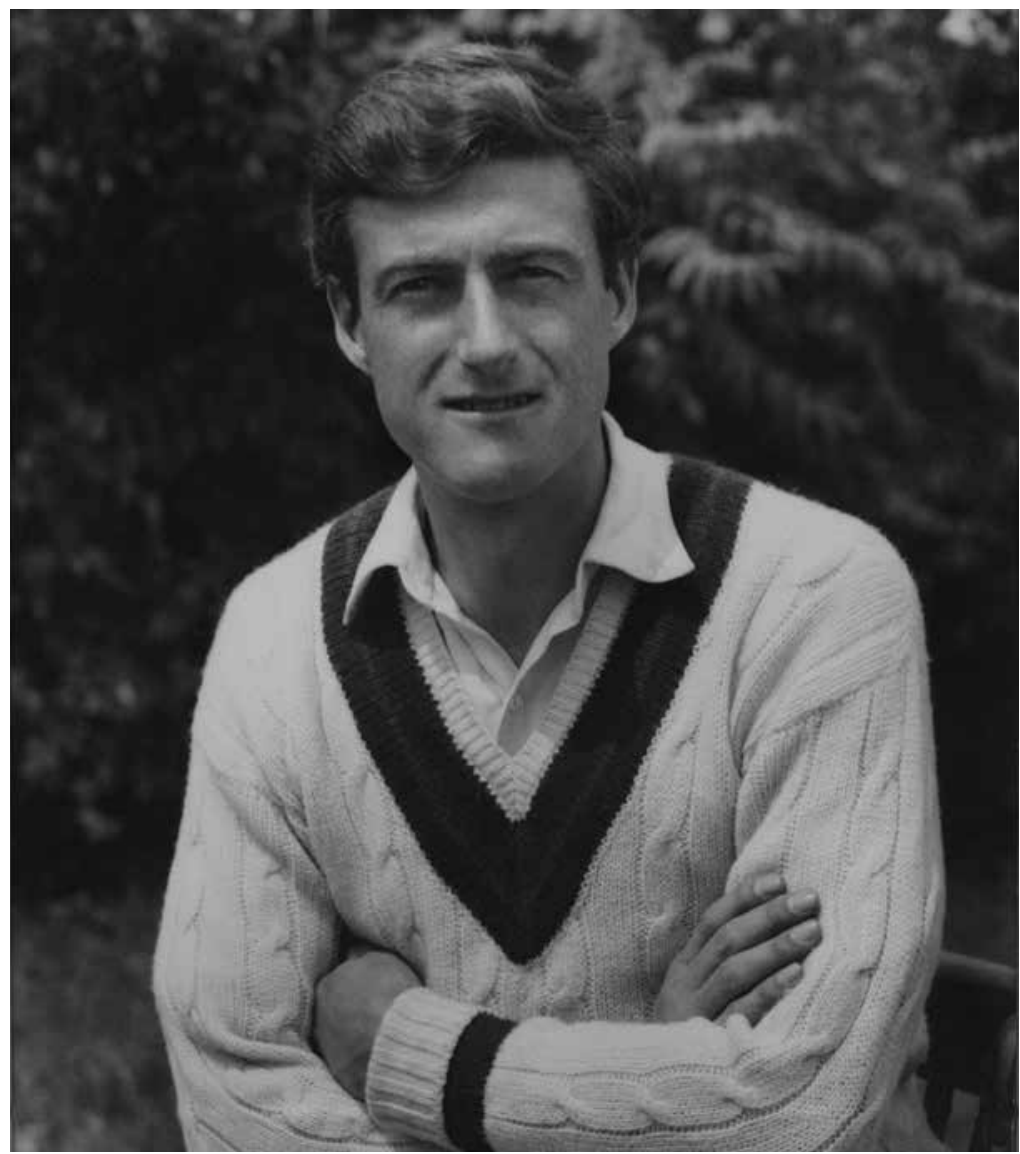

1 Sir Colin Stansfield Smith; a gifted cricket all-rounder, as well as an award winning architect

prone to overheating in summer, cold in winter, and dependent on expensive mechanical ventilation. Just as grievously for Stansfield Smith, they were often downright ugly, set amid barren wastes of tarmac, mown grass and chain-link fencing - ordered economically 'by the mile', as he quickly discovered. In the wake of the global oil crisis these deficiencies gave him the 'functional pegs' with which to persuade Council members, suspicious of all things 'arty', to do things differently.
The depredations of the Thatcher years still lay in the future and the Leader of the Council, Freddie Emery-Wallis, was an old-style Tory who viewed the County much as an eighteenth-century gentleman viewed the family estate; something to be 'improved' for future generations. Without Emery-Wallis's backing, vision and political skills it is doubtful if anything of note could have been achieved. Conveniently, the Chairman of the Council, Lord Porchester, was Chairman of SCOLA 


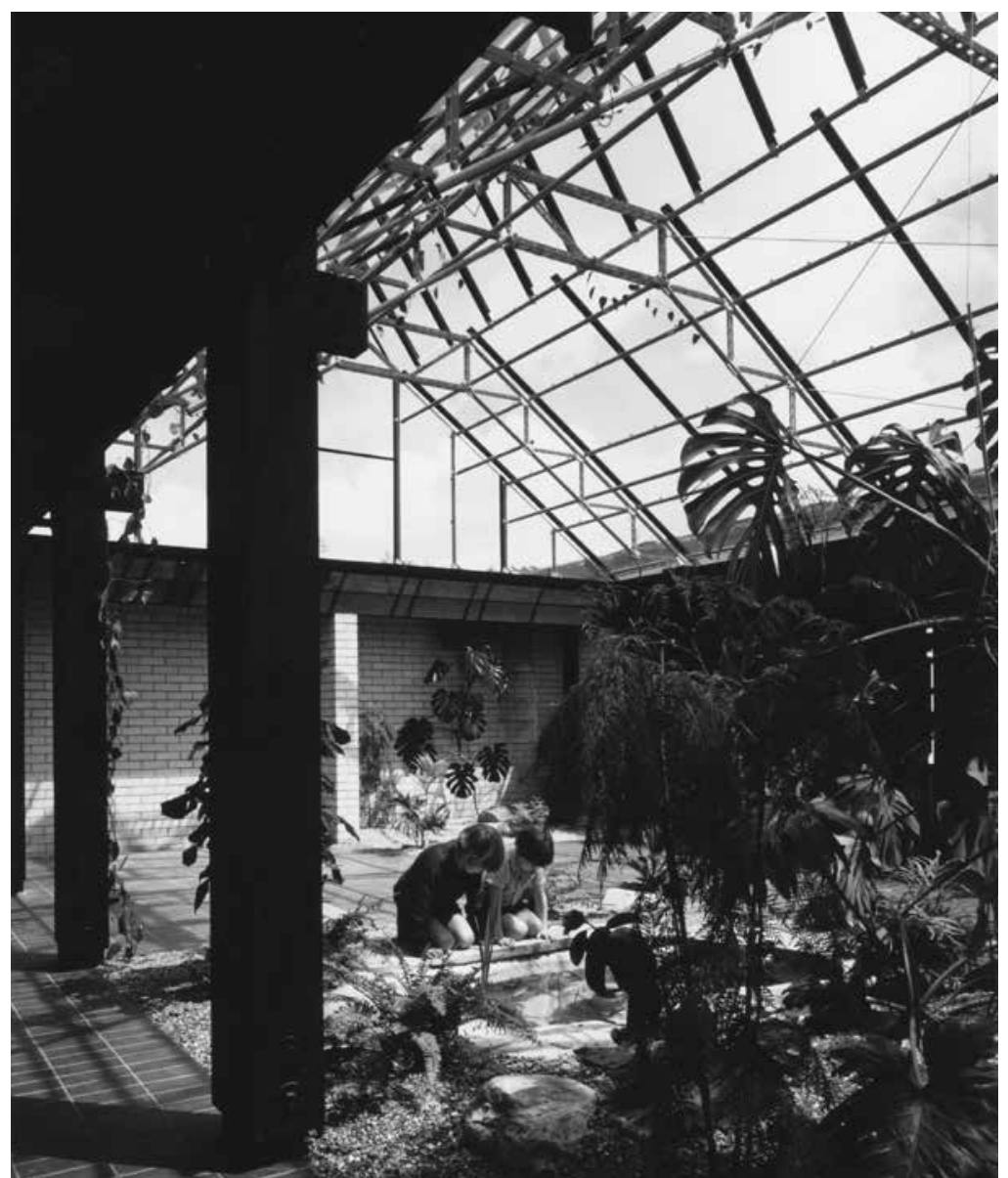

2 Yateley Newlands School, Hampshire, UK (1979). View of the atrium, as featured on the cover of The Architects' Journal, 24 June 198

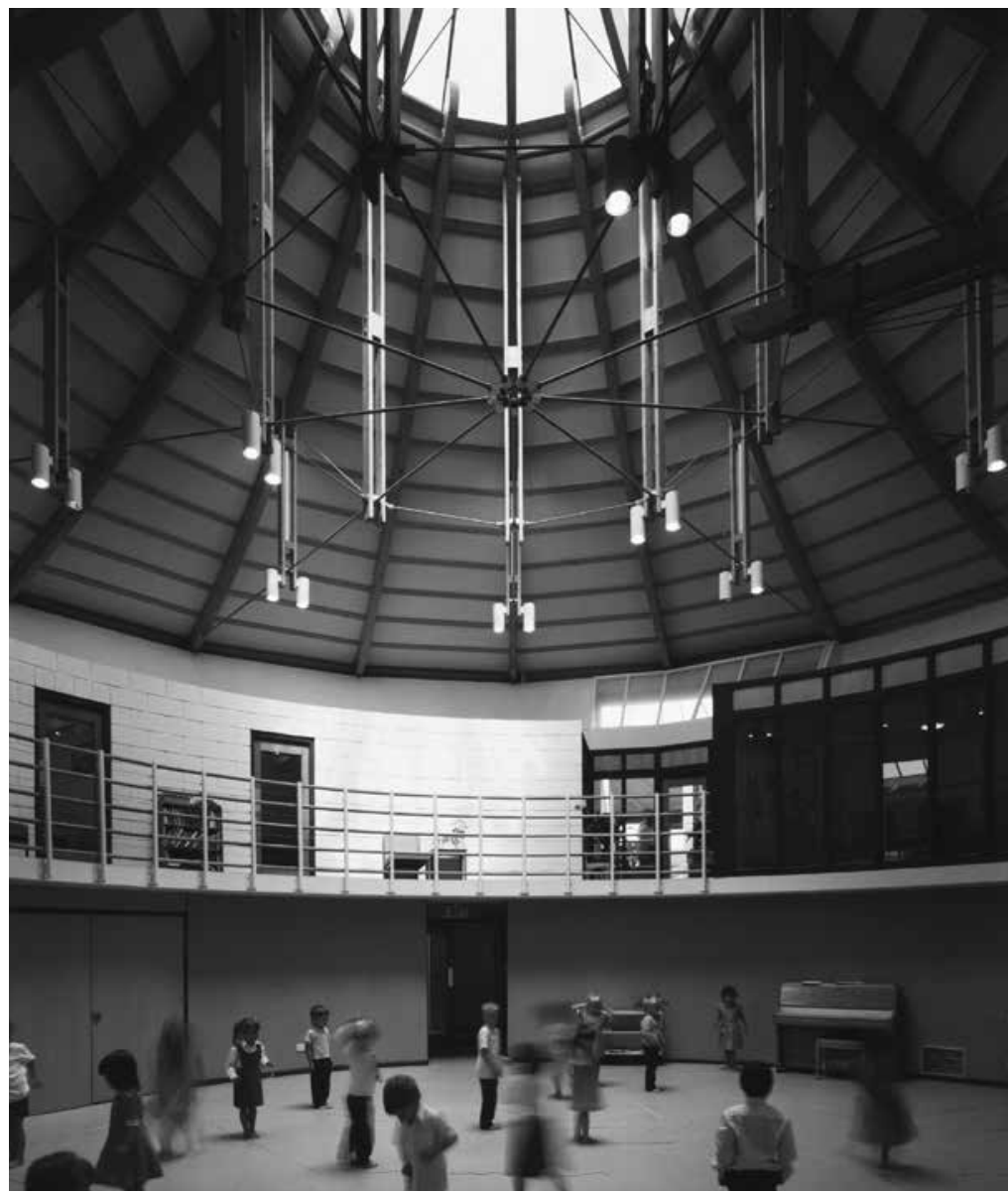

3 Bishopstoke School, Hampshire, UK (1989); view of the interior of the hall and also a cricket-lover who held first-class matches on his estate at Highclere Castle. Stansfield Smith, naturally, was invited to join Porchester's 'XI', offering an ideal opportunity for gentle lobbying.

Stansfield Smith was a gifted draughtsman, watercolourist and designer and always wanted to be known as a designing architect. But much of his time was, inevitably, taken up with management, especially in the early years. He introduced searching design reviews and re-organised the office into geographically-defined project teams with responsibility for all building types. 'It seemed obvious,' he observed, 'that the last person you wanted designing fire stations was someone who had been designing them for the last ten years.' On the same principle, he invited leading architects like Ted Cullinan and Michael Hopkins to design schools - precisely

because they had no experience of the building type, as he explained to the shocked Education Committee. He even dared to talk to heads and teachers, who normally had no say in the briefing process. Stansfield Smith's management style was aptly summed up in a parody of Gilbert and Sullivan written by a thespian on the staff: 'I analyse each project and I never follow policies / Unless of course the policies are Freddie Emery-Wallis's'.

Architecturally, an early sign of 'things to come' was a special needs school at Fareham that opened in 1978. It was the work of David White, a talented designer recruited to lead the new West Division. Organised around shared circulation and work areas with domestic-scale classrooms opening into monopitched roofs, it contained the seeds of much that was to come. Tragically, White did not live to see the office in its heyday, dying prematurely in 1985 .

In 1979, Stansfield Smith's deepening concern with passiveenergy design acquired a strong focus with the appointment of Derek Poole as Deputy County Architect. He had just completed a major Design Guidance Note on energy for the Department of Education and Science and brought with him a range of contacts among leading academic researchers.

By the early 1980s, the Hampshire office's buildings were appearing regularly in the national architectural press but it was surely the cover of The Architects' Journal of 24 June 1981 


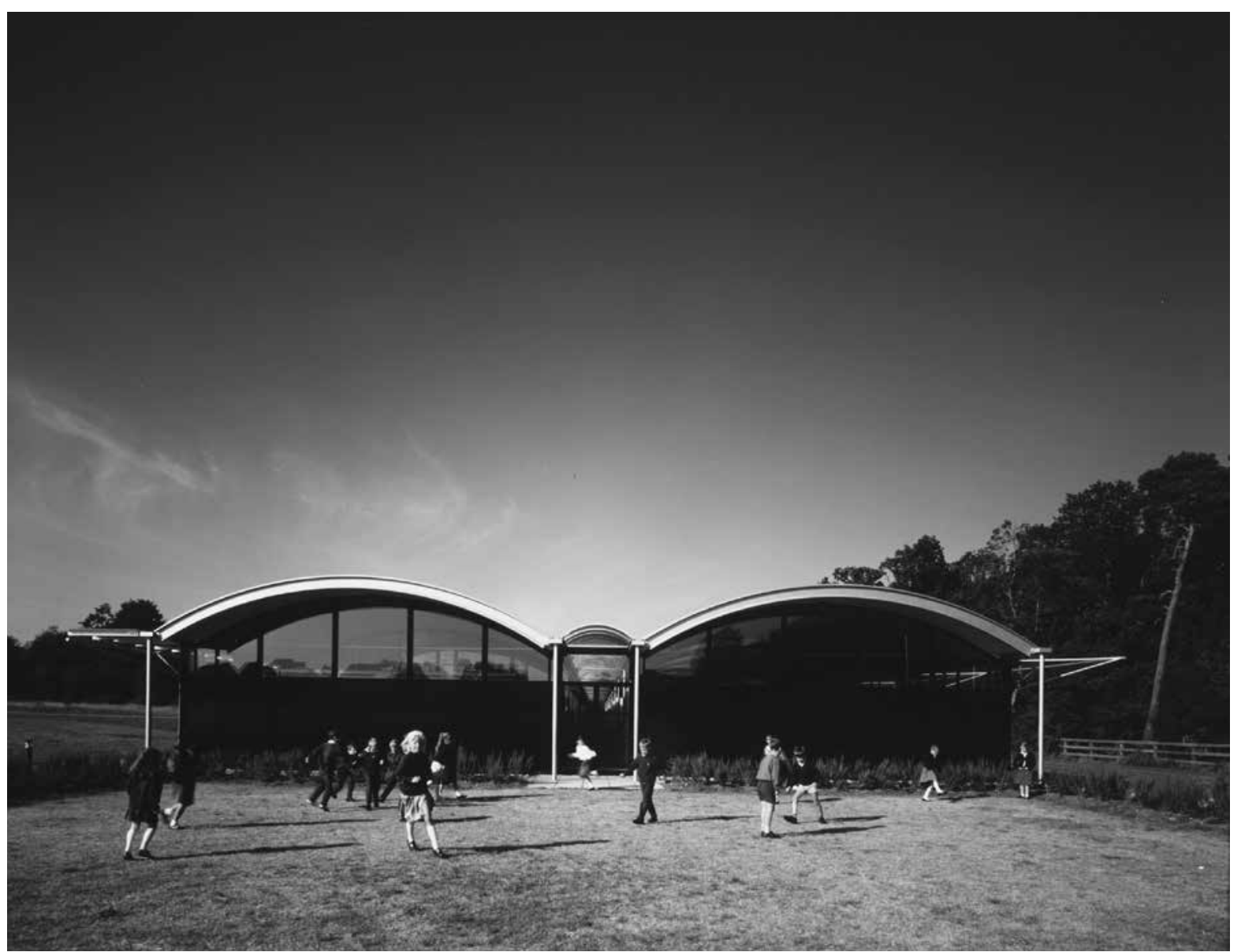

4 Queen's Inclosure Middle School, Hampshire, UK (1990); exterior sectional view

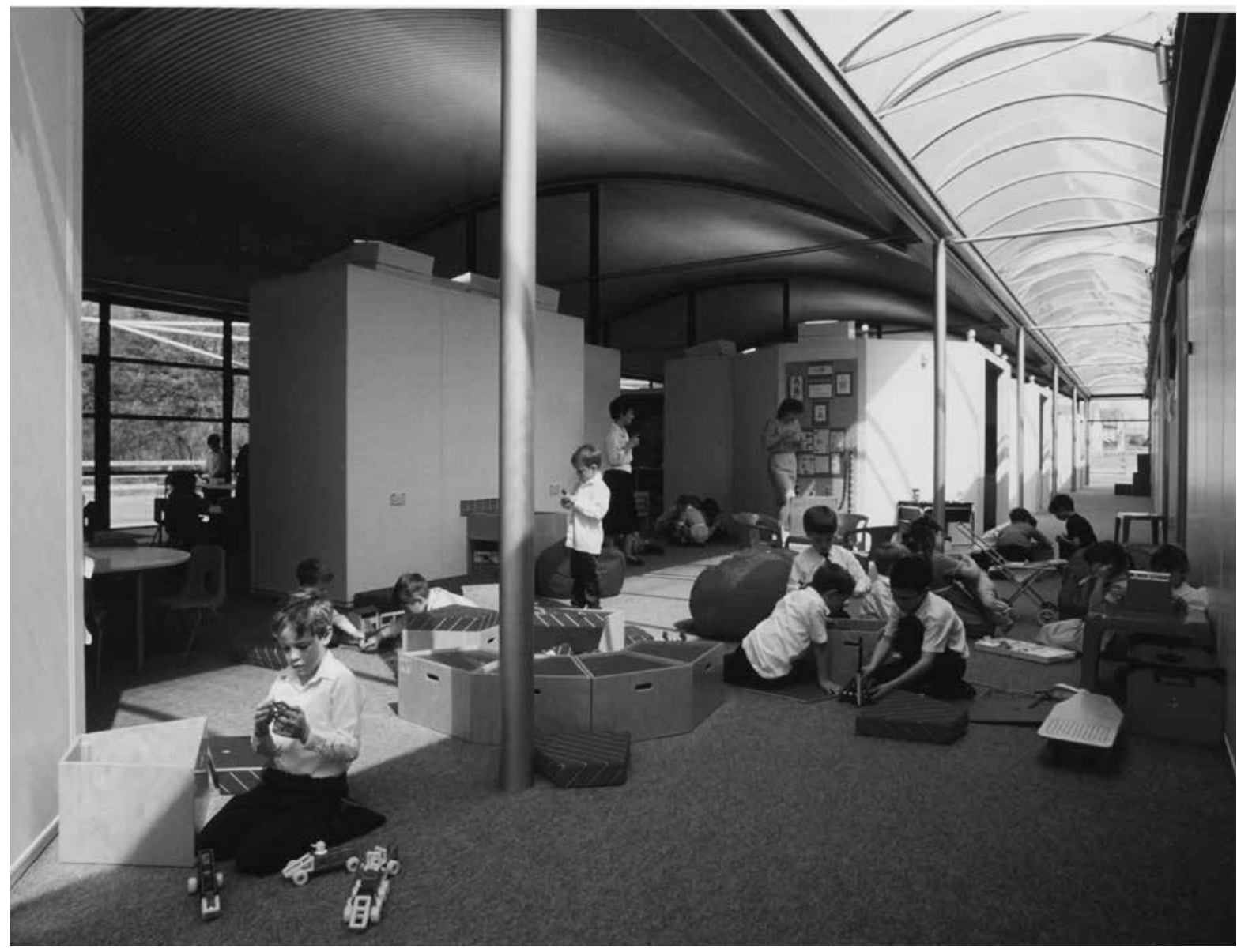

5 Queen's Inclosure Middle School (1990); interior view 
that made it clear something very special was afoot. It featured a picture of two boys playing in a verdant conservatory beneath a remarkably delicate-looking steel and glass roof. Yateley was designed by Mervyn Perkins, who had worked on an energy-efficient school as his thesis subject at the Portsmouth School of Architecture, and the conservatory formed a link between a naturally lit and ventilated deep-plan block of classrooms, and the hall and other shared facilities, both topped by open pitched roofs. Yateley's glass roof did not look like the kind of thing local authorities could afford - and indeed it wasn't, at least not without a little improvisation. It was designed 'on the side' by a member of Ove Arup's Lightweight Structures group and made, in his own garage and for a mere £6ooo, by the industrial designer Tony Pritchard. Long after, Stansfield Smith still recalled the moment when Pritchard arrived with the entire roof structure in the boot of his car!

The environmental logic of the 'big roof' was quickly expanded into a range of forms, from 'barns' and 'tepees' - splendidly delivered in a primary school at Bishopstoke - to the 'blanket' laid over the deep-planned Hulbert Middle School at Waterlooville, one of David White's last projects. Developed alongside the new generation of atrium office buildings, the Hampshire schools surely did more than any other body of work to introduce the potential - and necessity - of passive design to the practising profession in the UK.

Almost as notable as the airy, environmentally driven sections was the elimination of traditional corridors in favour of what became known as an internal 'street'. At Crestwood Secondary School in Eastleigh, Stansfield Smith tried to push this idea to its limits by envisaging the arcade between the two school buildings as a public thoroughfare. It was deemed to be a security risk and kept private. Happily the same fate did not befall the similarly socially ambitious design of the John Darling Mall in Eastleigh, a 'transitional' residential facility for people recovering from physical and mental trauma covered with a 'blanket' of transparent profiled sheeting. Its design split the
Social Services department, many of whom thought something 'normal and domestic' was needed, but it was widely acclaimed as an outstanding contribution, architecturally and programmatically, to designing for those with special needs.

Among the later schools, two totally contrasting designs were of special note. The steel-framed Queen's Inclosure Primary School in Cowplain, Waterlooville,

which opened in 1990, brought a new lightness of construction and openness in plan. It was complemented the following year by its antithesis in timber. Set into an east-facing slope below iron-age earthworks, the Woodlea Primary School in Bordon resembles a village of monopitched roofs clustering around a landscaped central space, with timber decks outside the classrooms for children's study and play. It won a BBC design award and reflected the values of another nationally influential spin-off from Hampshire County Council, the 'Learning Through Landscapes' movement.

Stansfield Smith was a vigorous advocate of the value of art in public places and took particular

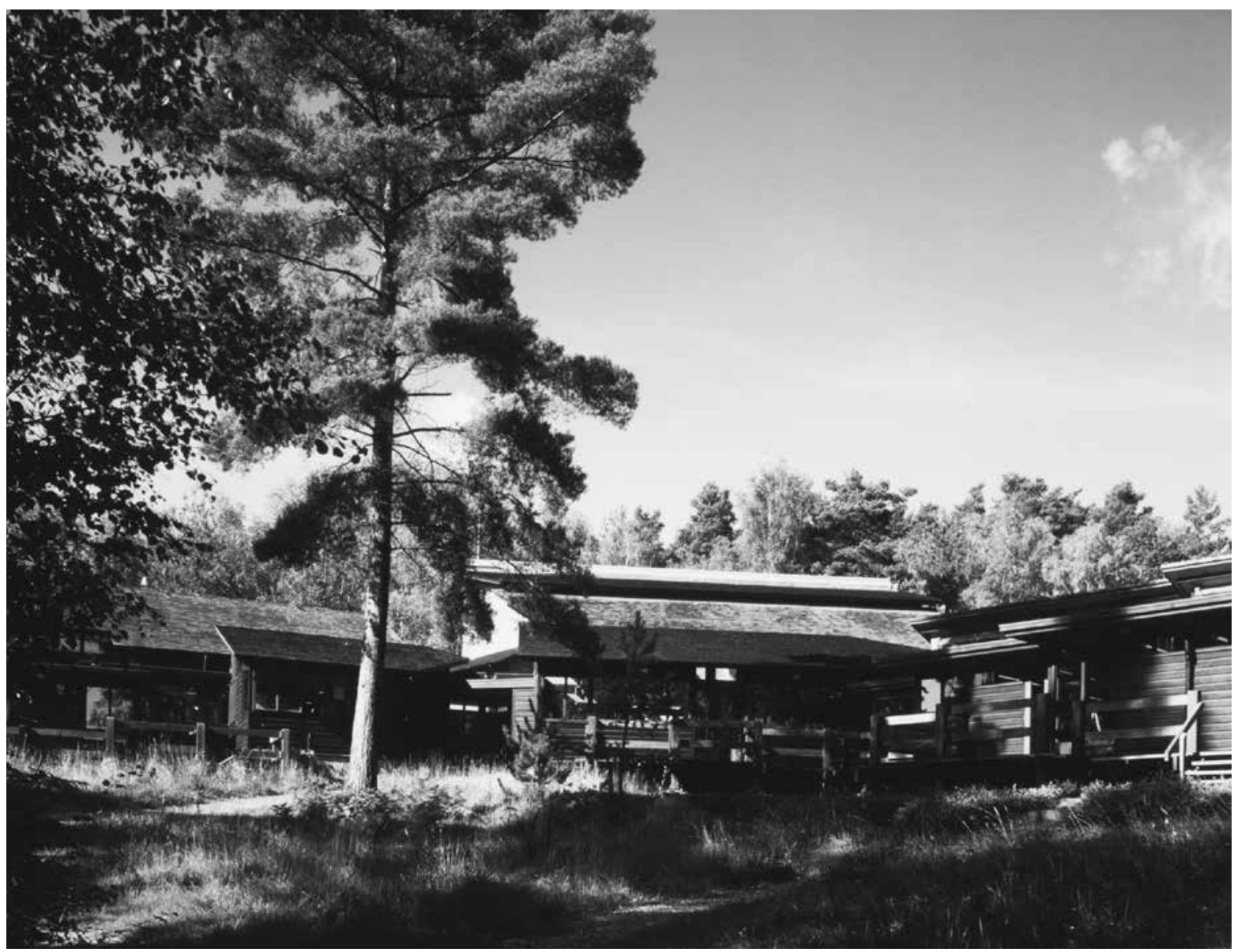

6 Woodlea Primary School, Bordon, Hampshire, UK (1993) 
delight in remedying the sins of his predecessors. Under his direction, the lofty interiors of Victorian primary schools were opened up, using the same energy-saving 'peg' that had been invoked to justify the installation of suspended ceilings in the first place. At the Bridgemary Community School in Gosport, completed in 1984, he took a typically bleak SCOLA environment, ripped up the chainlink fences and built walls to link the best existing buildings. A new courtyard was formed as the heart of a compact campus: 'a walled garden, for growing children rather than just plants', as he described it.

Alongside his manifold responsibilities as Chief Officer and design critic, Stansfield Smith always liked to have one 'personal project' on the drawing board. The Chandler's Ford library perfectly illustrates the strategic thinking that was one of his greatest assets. The site was on the edge of the town and accessed from a small road off the High Street. Stansfield Smith quickly realised that it would be possible to open up a pedestrian path from the High Street and offer the newly accessible adjacent land for commercial development. The resulting sale paid for building the new library.

Throughout his two decades as Hampshire County Architect, Stansfield Smith took a keen interest in the wider profession and in education in particular. At the RIBA, he helped to pioneer the idea of transforming 66 Portland Place into a public Architecture Centre - and, incidentally, solved the problem of elegantly integrating ramps into its steps to make it universally accessible.

He served as an external examiner and member of the RIBA Visiting Board in those distant days when the 'RIBA VB' was stocked with distinguished practitioners, and in 1990, was appointed Professor of Architecture at the Portsmouth School of Architecture, where he hoped to develop his vision of deploying and expanding the School's research interests by using the management of Hampshire's vast estate as a living 'laboratory'. A new building for the School ensued and, two years later, in a climate of rapid change in local authorities, the Professorship became his primary concern. For the County, he assumed the roles of Consultant County Architect and leader of a design unit intended to take on projects of major public value. Active to the end, Stansfield Smith filled his 'retirement' with continuing work in education and practice. Various competitions were won in association with younger practices, notably that of John Pardey. He served as a judge on the juries for many more, and as a Trustee of Portsmouth's Historic Dockyard. But it is for his work as Hampshire County Architect that he will above all be remembered, the results of which deserve to rank alongside that earlier flowering of educational buildings in Hertfordshire as among the finest achievements in the public sector in Britain.

RICHARD WESTON

Richard Weston is an architect, landscape architect, author and designer. His dozen books include Modernism, winner of the International Book Award of the American Institute of Architects; Alvar Aalto, winner of the Sir Banister Fletcher Prize; and what was described in Blueprint as possibly the finest monograph ever produced about an architect, on the work of Jørn Utzon, architect of Sydney Opera House

\section{Illustration credits}

arq gratefully acknowledges: Oliver Stansfield Smith, all images 


\section{Archaeological Dialogues}

\section{Editors}

Michael Dietler, University of Chicago, USA

Sarah Tarlow, University of Leicester, UK

Jeremia Pelgrom, Koninklijk Nederlands Instituut, Rome, Italy

Archaeology is undergoing rapid changes in terms of its conceptual framework and its place in contemporary society. In this challenging intellectual climate, Archaeological Dialogues has become one of the leading journals for debating innovative issues in archaeology. Firmly rooted in European archaeology, it now serves the international academic community for discussing the theories and practices of archaeology today. True to its name, debate takes a central place in Archaeological Dialogues.

\section{Price information}

is available at: http://journals.cambridge.org/ard

\section{Free email alerts}

Keep up-to-date with new material - sign up at http://journals.cambridge.org/ard-alerts

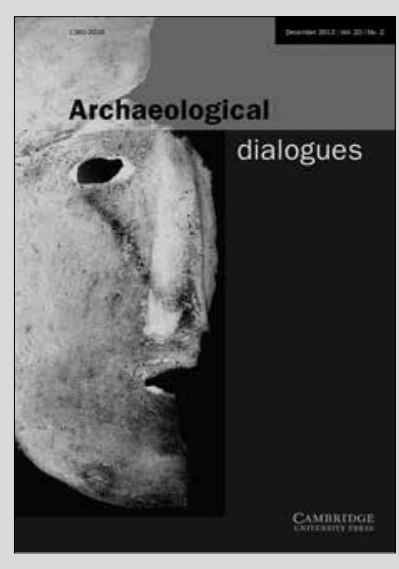

Archaeological Dialogues is available online at: http://journals.cambridge.org/ard

To subscribe contact Customer Services

\section{in Cambridge:}

Phone +44 (0)1223 326070

Fax $+44(0) 1223325150$

Email journals@cambridge.org

\section{in New York:}

Phone +1 (845) 3537500

Fax +1 (845) 3534141

Email

subscriptions_newyork@cambridge.org 